\title{
Effect of breed on meat quality and global acceptance of native lambs and their crosses
}

\author{
R.R.P. Lage ${ }^{1}$, W.H.O. Vega ${ }^{1 \#}$, H.H.A. Costa ${ }^{1}$, A.C. Costa ${ }^{1}$, L.C.O. Sousa ${ }^{1}$, L.D. Lima ${ }^{1}$ \& A.V. \\ Landim ${ }^{1}$ \\ ${ }^{1}$ Centre of Agrarian and Biological Sciences, Department of Animal Science, State University of Vale do Acaraú -UVA, \\ Betânia, CEP: 62040-370, Sobral, CE, Brazil \\ ${ }^{2}$ Embrapa Goats and Sheep, Fazenda Três Lagoas, PO Box 71, CEP: 62010-970, Sobral, CE, Brazil
}

(Received 12 September 2018; Accepted 4 January 2020; First published online 17 March 2020)

Copyright resides with the authors in terms of the Creative Commons Attribution 4.0 South African License.
See: http://creativecommons.org/licenses/by/4.0/za
Condition of use: The user may copy, distribute, transmit and adapt the work, but must recognize the authors and the South African
Journal of Animal Science.

\begin{abstract}
International projections point to the growth in global production of sheep meat, mainly from developing countries. However, the exigencies of consumers on characterization of production systems, nutritional information, and sensorial analysis to target the preferences must be answered. The aim of this study was to characterize the meat quality and the global acceptance of Brazilian native ovine breeds and their crosses, and discuss these aspects on the current basis of human health and wellbeing. Three native breeds (Morada Nova, Rabo Largo, and Santa Inês) that were managed in semi-intensive systems and raised in semi-arid Brazilian regions were used. Chemical composition and fatty acid analysis, sensory evaluation and health indices were accessed. The combined effects of breed, sex and breed by sex interaction produced differentiation in meat fatty acid (FA) profiles. The cholesterol contents ranged between 51 and $59.1 \mathrm{mg} / 100 \mathrm{~g}$. The Morada Nova lambs showed the lowest lipid content (1.93\%). The Morada Nova $x$ Rabo Largo crossbreed breed has the potential to increase the content of conjugated linoleic acid. The high content of $\alpha$-linolenic acid, which is considered hypocholesterolemic, was responsible for better health indices. The moderate acceptability obtained in sensory traits is compatible with the requirements of the consumer market. The combination of nutritional and sensory traits associated with human health and wellbeing that is presented by these native ovine breeds qualifies them as a good choice of red meat to be included in a larger proportion in human food.
\end{abstract}

Keywords: fatty acids, healthier meat, semi-arid region, sheep

\#Corresponding author: wilortvet@yahoo.es

\section{Introduction}

Red meat is an essential component of the diet in many populations, contributing to reducing malnutrition in developing countries via its supply of protein and key micronutrients (McNeill \& Van Elswyk, 2012). There is consensus on the importance of these dietary factors in human health. Ruminant-derived meat fat has received special focus because of its unfavourable relationship with cardiovascular disease and cancer (Stewart \& Wild, 2014; Sacks et al., 2017). This is due mainly to its high content of saturated fatty acid (SFA), which is classically related to elevated plasma low density lipoprotein (LDL) and increased cardiovascular risk (Santos et al., 2013). In Brazil, the rapid growth in meat consumption (beef, pork, and poultry) in the last five decades (from $32 \mathrm{~kg}$ in the mid-1970s to $91 \mathrm{~kg}$ at present), the adoption of a dietary pattern with high saturated fat and sugar, and foods with low fibre content have raised concerns among health agencies (Santos et al., 2013; CONAB, 2017).

On the other hand, compared with beef, sheep meat has higher proportions of omega $(n)-3$ polyunsaturated fatty acids (PUFAs), and PUFA biohydrogenation intermediates (PUFA-BHI), including conjugated linoleic acid (CLA), which are related to potential beneficial effects on human health and wellbeing (Calder, 2015; Chikwanha et al., 2018). Sheep meat consumption occupies the fourth position among the major livestock species, the world average being about $1.7 \mathrm{~kg}$ per capita annually (OECD, 2018). Interestingly, when the international guidelines on health and consumption of animal fats are reviewed, 
sheep meat is not included (Santos et al., 2013; Van Horn et al., 2016; Faludi et al., 2017; Sacks et al., 2017).

In contrast to the world average, the pattern of higher consumption per capita in regions such as Northeast Brazil, North Africa, Middle East and India is related to sheep meat being a primary animal-source protein ( Montossi et al., 2013; Costa \& Gonzalez, 2014). Semi-intensive production systems, locally adapted native breeds, semi-arid climatic conditions, and culinary and socio-cultural aspects give special characteristics to sheep meat that is consumed in these regions (Montossi et al., 2013; Carvalho et al., 2016; Hajji et al., 2016).

International projections point to a growth in global production of sheep meat, mainly from developing countries (FAO, 2011). However, the demands of consumers for characterization of production systems, nutritional information, and sensorial analysis to target their preferences must be answered (Montossi et al., 2013).

The fatty acid (FA) profile of meat in sheep is influenced by aspects such as feed, production system, sex, and breed (Díaz et al., 2005; Rovadoscki et al., 2018). Brazilian sheep meat production derives fundamentally from native breeds that are raised in semi-arid regions. However, their FA profile and sensorial traits have not been completely characterized. The present study was, therefore, conducted to characterize the meat quality and overall acceptance through sensorial analysis in Brazilian sheep native breeds. The discussion of results on the scientific basis associated with human health was part of the main line of work.

\section{Materials and Methods}

Animal handling followed the Brazilian College of Animal Experimentation (COBEA) directives, and approved by the Ethics Committee of State University of Vale do Acaraú (UVA), Ceará, Brazil $\left(n^{\circ} 003.04 .015 . U V A .504 .02\right)$. For sensory analysis, written consent was given by all volunteers. The study was conducted at Centre for Research in Nutrition of Small Ruminants at Experimental Farm of UVA, in northeast Brazil.

The experimental design was a completely randomized balanced full factorial design (three genetic groups and two genders) with six treatments and five replications, in which each animal represented an experimental unit. Ten lambs of each breed were used in this study; that is, five males and five females were randomly selected and distributed in the three native breeds (Morada Nova (MN), crossbred Rabo Largo $x$ Morada Nova (RBxMN), and crossbred Santa Inês x Morada Nova (SIxMN). Thus, 30 Morada Nova ewes from different properties of region and adapted to the conditions of the experimental farm were mated with three rams of each breed. At birth, the lambs were weighed, identified, and housed until weaning in collective pens with access to solid diet (concentrate based on corn, soybean meal and limestone), in order to meet the requirements and weight gain of $150 \mathrm{~g} /$ day (NRC, 2007). Afterwards, and until slaughter, the feeding regime was replicated and all the animals, which were managed in a semi-intensive system (65 days), received supplementation with concentrate as a function of total live weight of the lot $(1.5 \%$ of the total live weight, adjusted weekly). Briefly, native pasture of thinned caatinga, supplemented with Canarana erecta lisa grass (Echinochloa sp), was provided ad libitum. The bromatological analyses of diet components are shown in Table 1, and were performed according to procedures described in Mizubuti et al. (2009).

All lambs were slaughtered at the same time, at $24 \pm 3.71 \mathrm{~kg}$ of average weight, following the standard procedure of Brazilian Ministry of Agriculture, Livestock and Supply (MAPA, 2017). After the slaughter, carcasses were identified and refrigerated for 24 hours at $4{ }^{\circ} \mathrm{C}$. Samples of each carcass were provided by a transverse section of the Longissimus lumborum (LL) muscle between the 11th and 13th ribs and were frozen at $-10^{\circ} \mathrm{C}$ for later evaluation. Meat FA composition was determined by chromatographic analysis of methyl esters (FAME) using $3 \mathrm{~g}$ of muscle sample (wet) in a gas chromatograph (GCMS-QP5050A, SHIMADZU, Brazil). To calculate the concentration of FAs of muscle sample the intramuscular fat proportion of the trimmed muscle was used. Extraction of intramuscular fat was performed using the methodology of Hartman and Lago (1973). Fatty acid methyl esters were identified based on retention times compared with those of the standard FAME mixture using Sigma ${ }^{\circledR}$ reference standards (Sigma, St. Louis, MO, USA). Data for FA composition were expressed in percentage by weight of total identified FAs, and expressed as mg per $100 \mathrm{~g}$ muscle sample.

Each quality parameter was evaluated from the $L L$ muscle sample. The centesimal composition, moisture content (method 930.15), ash (method 920.153) and crude protein (method 928.08) were determined according to the AOAC (2012). Lipids were extracted and quantified following the methodology described by Folch et al. (1957) and the cholesterol determination used the high performance liquid chromatography (HPLC) method.

Health indices related to cardiovascular risk such as the hypocholesterolaemic to hypercholesterolaemic ratio $(\mathrm{H} / \mathrm{H}:$ [(sum of oleic, linoleic, arachidonic, linolenic) /(sum of myristic and 
palmitic)]) (Santos-Silva et al., 2002) and linoleic to linolenic ratio (C18:2/C18:3) (Díaz et al., 2005) were calculated.

Table1 Nutritional analysis of dietary components for finishing lambs

\begin{tabular}{lccc}
\hline \multirow{2}{*}{ Chemical composition (g/kg DM) } & \multicolumn{3}{c}{ Diet components $^{2}$} \\
\cline { 2 - 4 } Dry matter (DM) as feed & Canarana grass & Native pasture $^{1}$ & 929 \\
Organic matter (OM) & 918 & 906 & 945 \\
Crude protein & 872 & 894 & 368 \\
Ether extract & 51.6 & 155 & 40.0 \\
Neutral detergent fibre & 12.8 & 25.0 & 169 \\
Acid detergent fibre & 758 & 626 & 96 \\
Hemicellulose & 430 & 306 & 73 \\
Cellulose & 325 & 320 & 94.3 \\
Lignin & 347 & 242 & 3.7 \\
In vitro digestibility DM & 46.1 & 44.7 & 730 \\
In vitro digestibility OM & 310 & 450 & 813
\end{tabular}

${ }^{1}$ Main herbaceous species: vassourinha-de-botão (Borreriaverticillata G.F.W Mayer), marianinha (Commelina difusa Burnm. F), capim-milhã (Digitaria Sanguinalis (L.). Scop), forage peanuts (Arachis pintoI), algodão de seda (Calotropis procera), erva de ovelha (Stylosanthes humilis), jitirana lisa (Ipomea glabra Choisy), jitirana peluda (Jacquemontia asarifolia L. B. Smith), bamburral (Hyptissu aveolens), beldroega (Sesuvium portulacastrum)

${ }^{2}$ Corn, soybean meal and limestone

The sensorial analysis were performed according to procedures described by Landim et al.(2011). The $L L$ muscle at the 13th rib was used. Briefly, samples were cut in $1-\mathrm{cm}^{3}$ cubes and roasted in a preheated oven to $170{ }^{\circ} \mathrm{C}$. They remained there until the meat temperature was $71{ }^{\circ} \mathrm{C}$ at the geometric centre of the cube. Thirty non-trained judges indicated the intensity of sensation on a 9-cm linear scale. The responses were on a 1 to 9 scale. Each judge received the meat in an individual cabin in plastic containers coded with random three-digit numbers. Between tasting the first sample and the next, each taster received a glass of water at room temperature and a cracker-type biscuit, in order to remove the residual taste from the mouth. Sensations included hardness (perception of force necessary to cut the sample when bitten), succulence (perception of quantity of liquid liberated by the sample of meat in the mouth), taste (sensation of flavour liberated by the sample during chewing), aroma (sensation of smell liberated by the sample during chewing), and overall acceptance (evaluator's opinion of preference and acceptability based on all these attributes). Hardness varied from extremely soft (1) to extremely tough (9); succulence from extremely dry (1) to extremely succulent (9); flavour from bland (1) to extremely tasty (9); aroma from absent (1) to strong (9); and overall acceptance from low (1) to high (9).

To identify the effects of breed and sex on these traits, analysis of variance (ANOVA) was carried out for the chemical composition of meat data, followed by Duncan tests, while two-way ANOVA was performed for sensory and FA data to determine the significance in the breeds (G), sex (S) and interaction of sex by breed $(G \times S)$, followed by the Kruskall Wallis and Duncan tests, respectively. A statistical general linear model (GLM) was used. The existence of effect was considered when $P$-value was below 0.05 . The results are presented as least square means with standard errors.

To determine the variance components of overall acceptance of a sensorial trait, mixed models of predictive equation using the sensorial attributes and FA acid profile were tested. The restricted maximum likelihood (REML) method was used to estimate the variance components. The effect of the terms in the regression equations was examined by ANOVA for each response. The terms that were found as non-effect were excluded from the initial model, and the experimental data were refitted only to the effect $(P<0.05)$ parameters. In estimating the best regression model, the one with higher values of $R^{2}$ and adjusted $R$-square and lower Bayesian information criteria (BIC) was considered, Pearson's correlation coefficients ( $r$ ) were calculated to identify associations among sensorial attributes and FA composition (in grams and percentage) and meat chemical composition. No more than five variables were analysed at a time, in order not to 
compromise the analysis results (Granato et al., 2014). All statistical analysis was conducted using IBM SPSS Statistics 22 for Windows (SPSS Inc., IBM Corporation, NY, USA).

\section{Results}

The chemical compositions of meat in Brazilian native sheep breeds are shown in Table 2. The meat lipids content was higher in RBxMN compared with MN lambs and similar to SIxMN. Moisture, protein, ash and cholesterol components are similar between breeds $(P>0.05)$. Male lambs showed higher moisture content than female.

Table 2 Chemical composition of meat from native breeds of sheep as affected by sex

\begin{tabular}{|c|c|c|c|c|c|c|}
\hline \multirow[b]{2}{*}{ Nutrient } & \multicolumn{3}{|c|}{ Breed } & \multicolumn{2}{|c|}{ Sex } & \multirow[b]{2}{*}{ SE } \\
\hline & $\mathrm{MN}$ & RBxMN & SIxMN & Male & Female & \\
\hline Moisture, g/100g & 75.34 & 74.30 & 75.29 & $75.56^{a}$ & $74.48^{\mathrm{b}}$ & 0.246 \\
\hline Protein, $\mathrm{g} / 100 \mathrm{~g}$ & 21.23 & 21.38 & 21.26 & 21.37 & 21.24 & 0.222 \\
\hline Lipids, g/100g & $1.93^{b}$ & $2.81^{a}$ & $2.39^{\mathrm{ab}}$ & 2.24 & 2.50 & 0.139 \\
\hline Ash, $\mathrm{g} / 100 \mathrm{~g}$ & 1.06 & 1.13 & 0.99 & 1.05 & 1.07 & 0.038 \\
\hline Cholesterol, mg/100g & 59.14 & 53.32 & 53.00 & 52.39 & 57.07 & 2.62 \\
\hline
\end{tabular}

MN: Morada Nova; RBxMN: Rabo Largo x Morada Nova; SIxMN: Santa Inês x Morada Nova

${ }^{a, b}$ Means between breeds and sex in the same row with different superscripts are different $(P<0.05)$

Nutritional contents in human food are generally expressed in $\mathrm{mg}$ of nutritional element per gram of tissue analysed. Table 3 shows the effects of various sheep native breeds on the FA content of $L L$ in mg per $100 \mathrm{~g}$ of muscle sample by weight of total identified FAs.

The levels of stearic and palmitic SFA were highest in all breeds, followed by margaric and myristic acids in similar amounts. Greater content of myristic acid (30.74) was found in RBxMN lambs compared with other breeds (8.69 in $\mathrm{MN}$ and 13.34 in SIxMN). The SIxMN lambs had the lowest content of margaric acid (13.16). The highest value was obtained in MN lambs (35.39). No differences between breeds were found in stearic and palmitic acids. No sex effect in saturated acids was detected by ANOVA. Only margaric acid showed interaction of breed by sex effect $(P<0.05)$.

The monounsaturated oleic FA was found in larger amounts and had effects among all breeds $(P$ $<0.01)$. The RBXMN lambs had the highest value (1476.4), followed by SIxMN (1071.2) and MN (663.5) lambs. Females showed higher values in palmitoleic acid than males $(P<0.05)$. The palmitoleic and oleic FAs showed interaction breed by sex effect $(P<0.05)$. The content of PUFA was led by linoleic acid, followed by arachidonic acid. No breed effect was observed in these FAs. The higher values in linolenic and rumenic FAs were obtained by RBXMN animals. The other two breeds showed similar results. No effects of sex and interaction breed by sex were found in PUFA.

Breed $x$ sex interaction effects $\left(G^{*} S\right)$ on MUFA and PUFA were found. With reference to the sum of total FAs, only MUFA differed between breeds $(P<0.01)$. Here, the crossbred breeds had greater values than $\mathrm{MN}$ lambs. A sex effect was detected in total PUFA with males having a significantly greater amount than females. 
Table 3 Means ( \pm SE) of fatty acid content of Longissimus lumborum (mg per $100 \mathrm{~g}$ of muscle) by weight of total identified fatty acids in sheep native breeds

\begin{tabular}{|c|c|c|c|c|c|c|c|c|c|}
\hline \multirow[b]{2}{*}{ Total fatty acids } & \multicolumn{2}{|c|}{$\operatorname{Breed}(\mathrm{G})$} & \multicolumn{3}{|c|}{$\operatorname{Sex}(S)$} & \multirow[b]{2}{*}{ SE } & \multicolumn{3}{|c|}{ Significance } \\
\hline & $\mathrm{MN}$ & RBXMN & SIxMN & M & $\mathrm{F}$ & & $G$ & $S$ & GxS \\
\hline IFP, \% & $1.93^{\mathrm{b}}$ & $2.81^{\mathrm{a}}$ & $2.39^{\mathrm{ak}}$ & 2.38 & 2.41 & 0.14 & * & ns & ns \\
\hline \multicolumn{10}{|l|}{ Saturated } \\
\hline C14:0 & $8.69^{b}$ & $30.74^{a}$ & $13.34^{b}$ & 18.89 & 19.522 & 4.77 & * & ns & ns \\
\hline C16:0 & 410.38 & 502.19 & 485.26 & 404.47 & 514.68 & 32.70 & ns & ns & ns \\
\hline C17:0 & $35.39^{\mathrm{a}}$ & $30.42^{\mathrm{ab}}$ & $13.16^{\mathrm{b}}$ & 17.10 & 22.17 & 4.02 & * & ns & * \\
\hline C18:0 & 524.15 & 556.67 & 592.34 & 558.20 & 557.27 & 27.43 & ns & ns & ns \\
\hline \multicolumn{10}{|l|}{ Monounsaturated } \\
\hline $\mathrm{C} 16: 1$ & 9.53 & 16.68 & 13.79 & $7.47^{\mathrm{b}}$ & $21.21^{\mathrm{a}}$ & 3.30 & ns & * & * \\
\hline C18:1n9c & $663.5^{\mathrm{c}}$ & $1476.4^{\mathrm{a}}$ & $1071.2^{\mathrm{k}}$ & 1012.3 & 1117.3 & 94.31 & ** & ns & * \\
\hline C18:1n9t11 & 32.46 & 18.012 & 24.10 & 28.88 & 21.64 & 2.92 & ns & ns & ns \\
\hline \multicolumn{10}{|l|}{ Polyunsaturated } \\
\hline C18:2c9t11 & $5.27^{\mathrm{b}}$ & $20.44^{\mathrm{a}}$ & $9.48^{\mathrm{b}}$ & 12.09 & 13.44 & 2.35 & ** & ns & ns \\
\hline$C 18: 2 n-6 c$ & 194.99 & 155.05 & 205.51 & 185.14 & 183.95 & 15.73 & ns & ns & ns \\
\hline$C 18: 3 n-3$ & $7.96^{\mathrm{b}}$ & $25.71^{a}$ & $8.87^{b}$ & 19.21 & 9.30 & 3.17 & * & ns & ns \\
\hline$C 20: 4 n-6 c$ & 39.51 & 63.22 & 63.33 & 61.92 & 46.18 & 6.00 & ns & ns & ns \\
\hline$\Sigma S F A$ & 1018.3 & 1122.8 & 1108.3 & 1100.1 & 1059.8 & 60.46 & ns & ns & ns \\
\hline$\Sigma M U F A$ & $649.8^{b}$ & $1496.1^{a}$ & $1126.5^{\varepsilon}$ & 1050.4 & 1121.1 & 101.90 & $* *$ & ns & $* *$ \\
\hline$\Sigma$ PUFA & 240.47 & 192.48 & 261.24 & $270.46^{\mathrm{a}}$ & $190.21^{b}$ & 17.08 & ns & * & * \\
\hline
\end{tabular}

MN: Morada Nova; RBxMN: Rabo Largo x Morada Nova; SIxMN: Santa Inês x Morada Nova; IFP: percentage intramuscular fat; C14:0: myristic acid; C16:0: palmitic acid; C17:0: margaric; C18:0: stearic; C16:1: palmitoleic acid; C18:1n9c: pleic acid; C18:1n9t11: elaidic acid; C18:2c9t11: rumenic acid; C18:2n-6c: linoleic acid; C18:3n-3: linolenic acid; C20:4n6c: arachidonic acid. $\Sigma$ SFA: sum saturated fatty acids; MMUFA: sum monounsaturated fatty acids; 2 PUFA: sum polyunsaturated fatty acids GxS: breed by sex interaction; ns: non-significant

${ }_{a, b, c}$ Means between breeds and sex in the same row with different superscripts are different $\left({ }^{\star} P<0.05 ;{ }^{* *} P<0.01\right)$

The results for health indices were calculated, and their effects according to the FA profile in native lambs are shown in Table 4.

Table 4 Least square means for health indices based on the fatty acid profile of meat from native lambs

\begin{tabular}{|c|c|c|c|c|c|c|c|c|c|}
\hline \multirow{2}{*}{ Health indices } & \multicolumn{3}{|c|}{ Breed $(\mathrm{G})$} & \multicolumn{2}{|c|}{ Sex (S) } & \multicolumn{4}{|c|}{ Significance } \\
\hline & $\mathrm{MN}$ & RBxMN & SIxMN & M & $\mathrm{F}$ & SE & $\mathrm{G}$ & $S$ & GxS \\
\hline $\mathrm{H} / \mathrm{H}$ & $2.42^{\mathrm{b}}$ & $3.34^{\mathrm{a}}$ & $2.63^{\mathrm{b}}$ & 2.60 & 2.98 & 0.14 & * & ns & * \\
\hline C18:2/C18:3 & $18.49^{\mathrm{a}}$ & $7.93^{b}$ & $20.64^{a}$ & 14.01 & 18.83 & 2.17 & * & ns & ns \\
\hline
\end{tabular}

MN: Morada Nova; RBxMN: Rabo Largo x Morada Nova; SIxMN: Santa Inês x Morada Nova

$\mathrm{H} / \mathrm{H}$ : hypocholesterolaemic/hypercholesterolaemic ratio: [(sum of oleic, linoleic, arachidonic, linolenic) / (sum of myristic and palmitic)]; C18:2/C18:3: linoleic/linolenic ratio

a,b Means between breeds and sex in the same row with different superscripts are different $\left({ }^{*} P<0.05\right)$; ns: nonsignificant.

For the $\mathrm{H} / \mathrm{H}$ ratio, higher values are more desirable. The $\mathrm{RB}^{*} \mathrm{MN}$ lambs obtained the highest value (3.34) among the three breeds. The $\mathrm{MN}$ and SIxMN lambs obtained similar results (2.24 and 2.63, respectively). Breed interaction by sex was also presented. In the linoleic to linolenic ratio (C18:2/C18:3), 
minor values are desired. The minor value was obtained in RBxMN lambs (7.93). The MN and MNxSI lambs obtained similar results ( 18.49 and 20.64 , respectively).

Sensory analysis results of $L L$ muscle in native sheep breeds, according to breed and sex are shown in Table 5. There were no differences between breeds and sex in the sensory attributes.

Table 5 Sensory analysis of meat from the Longissimus lumborum of native lambs, by breed and sex

\begin{tabular}{lcccccc}
\hline & \multicolumn{5}{c}{ Breed } & \multicolumn{3}{c}{ Sex } & \multirow{2}{*}{ SE } \\
\cline { 2 - 5 } Attributes & MN & RBxMN & SIxMN & M & F & 0.278 \\
Aroma & 4.42 & 4.04 & 3.80 & 4.20 & 3.96 & 0.191 \\
Succulence & 3.66 & 3.80 & 4.41 & 3.99 & 3.93 & 0.140 \\
Flavour & 4.54 & 4.79 & 5.10 & 4.81 & 4.83 & 0.201 \\
Hardness & 3.80 & 3.58 & 3.36 & 3.93 & 3.03 & 0.128 \\
Overall acceptance & 4.51 & 4.85 & 5.12 & 4.76 & 4.90 &
\end{tabular}

MN: Morada Nova; RBxMN: Rabo Largo x Morada Nova; SIxMN: Santa Inês x Morada Nova

Aroma did not present extreme values in any of the breeds. The scores varied between 3.8 and 4.42 were classified as moderate. Meat samples of the breeds also presented medium succulence and moderate flavour. Regarding hardness of the meat, the three breeds were had scores that varied between 3.36 and 3.8. If 4.5 is considered the average value for overall acceptance, all breeds approached this value. Overall acceptance was classified as medium.

Predictive equations for the global acceptance sensorial trait and its succulence and flavour components are shown in Table 6. In this study, succulence and taste were the main sensorial traits that represent variance in the overall acceptance trait $\left(R^{2}=0.84\right)$. The succulence of meat depends mainly on the percentage content of margaric $F A\left(R^{2}=0.77\right)$. The lipid and percentage content of margaric FA (C17:0) explain the variations due to taste $\left(R^{2}=0.77\right)$.

Table 6 Predictive equation for overall acceptance sensory trait of meat and its component traits in meat from native lambs

\begin{tabular}{llcccc}
\hline Dependent variable & \multicolumn{1}{c}{ Model } & $\mathrm{R}^{2}$ & Adj R-Sq & BIC & $P$-Value \\
\hline Overall acceptance & $\mathrm{Y}=1.519+0.375(\mathrm{SUC})+\beta 20.400(\mathrm{TAS})$ & 0.84 & 0.83 & 27.0 & $<0.0001$ \\
Succulence & $\mathrm{Y}=4.893+-1.431(\mathrm{C} 17: 0)$ & 0.77 & 0.75 & 16.5 & $<0.0001$ \\
Flavour & $\mathrm{Y}=4.31)+-0.658(\mathrm{C} 17: 0)+0.315($ Lipid) & 0.77 & 0.71 & 7.2 & $<0.0001$ \\
& & & & & \\
\hline
\end{tabular}

Y: dependent variable, SUC: Succulence, TAS: Flavour, C17:0: margaric acid (\%), Lipid: lipid content (\%), $\mathrm{R}^{2}$ : determination coefficient, Adj R-Sq: adjusted R-square, BIC: Bayesian information content (smaller is better)

${ }^{1} P$-value for the model

Meat with lower succulence and taste was strongly correlated ( $r=-0.88$ and -0.80 , respectively) with a high content of margaric FA $(P<0.05)$. A moderated and negative correlation were found between margaric acid content $(\%)$ and overall acceptance $(r=-0.74)(P<0.05)$. The content of the PUFA arachidonic acid (C20:4n6c) was associated with harder $(r=-0.50)$ and less succulent $(r=0.66)$ meats $(P<0.05)$. The lipid content (\%) was moderately and negatively correlated with hardness of meat $(r=-0.50, P<0.05)$. Associations between lipid content (\%) and taste and overall acceptance were weaker and positive (0.31 and 0.33 , respectively) and significant at $P<0.09$. Other associations among sensorial attributes with $F A$ composition (in grams and percentage) and chemical composition were very weak. 


\section{Discussion}

Potential to increase affordability and availability of healthier foods relative to less healthy foods in developed and developing countries depends, among others, of validation of past trends and information, with more recent information about quality, consumption and lifestyle patterns (Muchenje et al., 2018).

In the chemical composition, lipid and cholesterol content are primary considerations in discussions of healthy meat. It is now clear that different dietary patterns modulate different aspects of the atherosclerotic process and cardiovascular risk factors. These include plasma lipid levels, insulin resistance and glucose metabolism, blood pressure, oxidative phenomena, endothelial function, and vascular inflammation. Consequently, dietary consumption patterns may lead to inference with regards to atherosclerotic events (Santos et al., 2013).

The lowest value in lipid content, which was obtained in meat from MN lambs (1.93\% of muscle) is therefore considered favourable. This difference may be related to the slaughter bodyweight of the MN lambs $(17.46 \mathrm{~kg})$ compared with RBXMN and SIxMN lambs (20.97 and $21.10 \mathrm{~kg}$, respectively). Despite the clear influence of weight on the lipid composition of carcass, small size and late growth are part of distinguishing breed characteristics of MN sheep.

Lipid content in German, British and Uruguayan (light and heavy) lambs from typical production systems in the respective countries was higher compared with the Brazilian native breeds, reaching values of 4.25, 4.32, 3.05 and $5.94 \%$, respectively (Díaz et al., 2005). These greater levels of fatness are probably related to the heavier slaughter body weight of these breeds. Recently, de Abreu et al. (2019) have shown that Dorper x Santa Inês lambs in Brazilian semi-arid production system ahev a degree of fatness that approaches the values obtained for meant from the RBxMN and SIXMN lambs. The beef lipid content in grass-fed heifers was also greater (4.6\%) to that obtained in the current study in the all groups (Berger et al., 2018).

Several international guidelines recommend the restriction of dietary fats and cholesterol, aiming at reducing and controlling plasma cholesterol and plasma LDL (Santos et al., 2013; Sacks et al., 2017). The Brazilian Guideline on Fats and Cardiovascular Health recommends a consuming not more than $300 \mathrm{mg} / \mathrm{day}$ of cholesterol (Santos et al., 2013).

The cholesterol content in this study ranged between 51 and $59.1 \mathrm{mg} / 100 \mathrm{~g}$ of muscle. This result contrasts with cholesterol concentrations in $\mathrm{mg} / 100 \mathrm{~g}$ muscle in species such as chicken (73.42), beef (70.22) and pork (65.42) (Montalvo-Puente et al., 2018). Muscle cholesterol values in Iranian fat- and thintailed sheep native breeds ranged between 62.25 and $82.85 \mathrm{mg} / 100 \mathrm{~g}$ meat (Aali et al., 2017), values that are also higher than those seen in this study. People with diabetes may have abnormalities in the cholesterol transport mechanism and may benefit from a decrease in dietary cholesterol intake (Djoussé \& Gaziano, 2008). The current results demonstrate the potential of these Brazilian native sheep breeds in reducing dietary cholesterol consumption from red meat.

The influence of FA intake on the risk factors of cardiovascular disease and plasma concentrations of lipids and lipoproteins has been widely demonstrated in experimental and population studies (Billett, et al., 2000; Hamley, 2017). Saturated fatty acids are cited as the main contributors to these harmful effects (Sacks et al., 2017). The greatest proportion of SFAs in this study was found in MN lambs. However, this result should be interpreted with caution. Because of the lower content of lipids (1.93\%) in this breed, the final concentrations in $100 \mathrm{~g}$ of muscle were not greater than in the other breeds (Table 4). Stearic acid (C18:0) was the main SFA, which contributes $53.5 \%$ (in RBxMN lambs) to $57.6 \%$ (in MN lambs) of the total SFA, followed by palmitic acid (C16:0) which was $41.3 \%$ to $44.8 \%$ of total SFA. Myristic acid (C14:0), which is considered more cholesterolemic, represented only $1.5 \%$ to $2.5 \%$ of total SFAs.

When the native sheep breeds from this study are compared with other sheep breeds and beef (Díaz et al., 2005; Borghi et al., 2016; Feitosa Braga et al., 2017), the distribution of SFA is different with higher concentrations in palmitic and myristic acids and lower content of stearic acid. The potency of individual longer-chain SFA ( $\geq 12$ carbons) in raising low-density lipoprotein-cholesterol (LDL-C) levels diminishes from myristic acid (C14:0) with increasing chain length up to stearic acid (C18:0), which generally has a neutral effect on lipid and lipoprotein levels ( Siri-Tarino et al., 2015; Nettleton et al., 2016). Thus, it can be suggested that meat consumption from these native breeds, and particularly SIxMN lambs, might be associated with a lower elevation of LDL-C levels if compared with meat from other sheep breeds or beef.

Commonly, most interest has been in reducing the negative health impact of FAs that are related to cardiovascular disease (CVD), but it is now clear that some FAs (MUFA and PUFA) have a positive influence on CVD and a range of other diseases (Chikwanha et al., 2018). Oleic acid, the major cis-MUFA that was found in this study in RBxMN lambs, contributed $52.5 \%$ of total FAs in this breed. This FA is associated with beneficial effects on the prevention of cancer, and autoimmune and inflammatory diseases (Sales-Campos et al., 2013) and reduction in LDL-C and triglycerides levels (Van Horn et al., 2016). In MN and SIxMN lambs the proportions of oleic acid were 34.7 and $42.9 \%$ of total FA, respectively. The results related by Chikwanha 
et al. (2018) in sheep (32.5\%) and beef meat (36.1\%) endorse this superiority in this study by the RBxMN breed. There is scientific consensus that high intakes of trans-MUFA (as elaidic acid) are detrimental to heart health (Brouwer et al., 2013; Souza et al., 2015). The proportion of elaidic FA ranged from 0.64\% (RBxMN lambs) to $1.7 \%$ (MN lambs) of total FA. Higher values were reported in Santa Inês lambs (2.43\%) (Lôbo et al., 2013) and Nellore beef (2.9\%) (Feitosa- Braga et al., 2017) in this FA. If one considers the MUFA ratios that were found in this study, and the theoretical basis that was supported, it can be suggested that the RBXMN breed shows a health advantage compared with other breeds and species.

A prospective nested case-control study in humans showed that compared with controls, people with total haemorrhagic and ischemic strokes had similar proportions of omega-3 PUFA (such as linolenic acid) and lower proportions of linoleic and arachidonic acids (Iso et al., 2002). In the current study, the PUFA content was led by linoleic acid, followed by arachidonic acid in all breeds. These results were similar to those in Spanish lambs and contrast with German, British and Uruguayan (light) lambs, in which the linolenic acid content also exceeded that of arachidonic acid (Díaz et al., 2005). It is contented that this result is due not only to the breed effect, but also to the semi-extensive management system of natural pastures containing mixed browse/shrubs and grasses (Lourenço et al., 2007). The caatinga plant secondary metabolites affect the PUFA profile as their presence culminates in higher duodenal flow rate compared with forage without these secondary metabolites (Fraser et al., 2004; Pinto et al., 2018). Higher intake of linoleic acid (an essential FA) may protect against ischemic stroke, possibly through potential mechanisms of decreased blood pressure, reduced platelet aggregation, and enhanced deformability of erythrocyte cells (Iso et al., 2002; Calder, 2015). Additionally, linoleic acid is a precursor of docosapentaenoic (DPA) $(22: 5 n-3)$, eicosapentaenoic (EPA) $(20: 5 n-3)$ and docosahexaenoic (DHA) $(22: 6 n-3)$ acids, which are associated with the promotion of cardiovascular, neural and mental health, lipid metabolism and endothelial cell migration and anti-inflammatory properties, which together suggest a strong role for prevention of CVD, inflammatory and metabolic diseases and cancer (Byelashov et al., 2015; O'Connell et al., 2017; Chikwanha et al., 2018). Priority should be given to the consumption of linoleic acid from animal sources due to the low conversion of EPA and DHA acids from vegetable sources (Santos et al., 2013). It is necessary to acknowledge the limitations of the current study that are related to the lack of detection of EPA, DHA, and DPA in the meat although the lipid content was moderate compared with other studies.

A unique characteristic of ruminants is the preferential incorporation of long chain n-3 PUFA into phospholipids as opposed to triacylglycerol, contributing to accumulation of PUFA-BHI, such as conjugated linoleic acid (CLA) (Chikwanha et al., 2018). Rumenic acid (RA) (C18:2c9t11), the main natural isomer of CLA, was found in major amounts in RBxMN lambs in this study (approximately $61.3 \mathrm{mg}$ per serving). Preliminary evidence suggests intakes of RA of about $0.80 \mathrm{~g} /$ day (from 0.6 to $3.0 \mathrm{~g} / \mathrm{d}$ ) are helpful in protecting against a range of diseases from cancer to atherosclerosis (Siurana \& Calsamiglia, 2016). A portion of meat from RBxMN lambs would contribute $7.66 \%$ of the recommended intake. Therefore, its meat would be an opportunity to increase consumption of CLA, principally RA, without requiring major changes to eating habits.

Another n-3 PUFA that is associated with reduced risk of fatal and non-fatal coronary heart disease (CHD) or composite CHD is a-linolenic acid (ALA) (C18:3n-3) (Wei et al., 2018). a-Linolenic acid content was also greater in RBxMN lambs $(25.71 \mathrm{mg} / 100 \mathrm{~g})$. This result may be due to the breed effect, since the feed management system was equal among the groups. The results obtained by Díaz et al. (2005) showed that lambs reared under intensive conditions, and fed concentrates and cereal straw, had low ALA content (9.72 $\mathrm{mg} / 100 \mathrm{~g}$, in Spanish lambs) as a consequence of the FA composition of the diet, since ALA is the major FA in grass. The ALA content was the trait with greater genomic heritability $\left(h^{2}=0.46\right)$ for FA profile in Santa Ines sheep, which would facilitate its genetic improvement through selection (Rovadoscki et al., 2018). Comparatively, sheep meat has more PUFA-BHI than beef, because of the smaller size of the rumen and consequent shorter retention times or higher passage rates of feed from the rumen, with consequent increased duodenal flow, absorption and deposition of PUFA and their BHI into tissues (Chikwanha et al., 2018).

The health indices results are in line with the MUFA and PUFA contents. The meat of RBxMN lambs was shown to be healthier by the $\mathrm{H} / \mathrm{H}$ and linoleic/linolenic $(\mathrm{C} 18: 2 / \mathrm{C} 18: 3)$ ratios. The higher content of $\mathrm{FAs}$ that are regarded hypocholesterolemic (oleic, rumenic and linolenic acids) explains these results. In the $\mathrm{H} / \mathrm{H}$ index, higher hypocholesterolemic FA values result in higher index values. Thus, indices with higher values are desirable. The results in all native breeds in this study (Table 5) were higher when compared with lle France lambs (1.45) (Borghi et al., 2016). Despite the advantages of ALA and LA acids, and due mainly to a large number of sources of LA in nature, it is necessary to maintain a balance in the consumption of these two PUFAs. The recommendation of Brazilian Guideline on Fats and Cardiovascular Health is from 5:1 to 7:1 (linoleic/linolenic ratio) of total intake (Santos et al., 2013). The RBxMN breed had this index within the recommended Brazilian guideline (7:1). The other native breeds showed higher values owing to the low 
content of linoleic acid. German, British and Uruguayan lambs had values of this ratio that ranged from 1:1 to 3:1. In Spanish lambs (Díaz et al., 2005), this ratio was in line with the other native breeds that were accessed in the present study.

An adequate balance of sensory traits is fundamental to potential consumption of native sheep meat. The results obtained here place these breeds within the range of moderate or medium acceptability based on the scores that were assigned to the sensory traits. Thus, meat from these breeds is seen as being compatible with the requirements of the Brazilian consumer market (Montossi et al., 2013), which supports the use of these sheep breeds. Regression analysis identified margaric FA and lipid content as the main variables explaining variation in overall acceptability of lamb meat, due mainly to their roles in determining succulence and meat flavour. For applications such as the evaluation of sensory data, the coefficient of determination may be considered good if $\mathrm{R}^{2}>60 \%$ (Granato et al., 2014). Sensory properties may be improved through genetic selection because of the moderate to high estimates of genomic heritability that were reported for components of the FA profile of meat from sheep (Rovadoscki et al., 2018). It is believed that genetic improvement should be directed at decreasing the margaric acid content. An increase in arachidonic acid content in meat is not necessary since the level is already high in concentrate-fed animals. Finally, cross-cultural studies of consumer acceptance could be vital in informing future marketing or regulatory strategies involving these breeds.

\section{Conclusion}

Based on the differences in FA profiles, crossbred Rabo Largo and Morada Nova lambs are thought to represent breeds with potential benefit to human health, mainly because of the MUFA and PUFA distribution and contents. The Morada Nova breed was highlighted because of its low lipid content, thus being indicated in diets in which the lipid intake from animal sources should be lower. All breeds have low cholesterol content, demonstrating their potential to reduce cholesterol consumption. The large effect of margaric FA in the prediction of overall sensory acceptance signals a useful starting point for improving the acceptance of meat from these breeds. This paper contributes to promoting better understanding of the meat quality and potential health benefits of FA profiles in native Brazilian sheep breeds. This information has values that are related to human health and wellbeing. Sheep meat production may benefit by including this health-related information in formulating future information and marketing campaigns.

\section{Acknowledgements}

The authors thank the Office to Coordinate Improvement of University Personnel (CAPES) for the grant awarded to the first author and the Cearense Foundation for the Support Scientific and Technological Development (FUNCAP) for financial support.

\section{Authors' Contributions}

AVL designed the study. RPL collected and analysed the data. WHOV and HEAC drafted and revised the manuscript. LCS and ACC collected the data. WHOV, LDL and AVL analysed the data and revised the manuscript.

\section{Conflict of Interest Declaration}

The authors have no conflicts of interest to declare.

\section{References}

Aali, M., Moradi-Shahrbabak, H., Moradi-Shahrbabak, M., Sadeghi, M. \& Yousefi, A.R., 2017. Association of the calpastatin genotypes, haplotypes, and SNPs with meat quality and fatty acid composition in two Iranian fat- and thin-tailed sheep breeds. Small Ruminant Research 149, 40-51. https://doi.org/10.1016/J.SMALLRUMRES.2016.12.026

AOAC, 2012. Official methods of analysis of AOAC international, 19th ed. Gaithersburg, Maryland, USA.

Berger, J., Kim, Y.H.B., Legako, J.F., Martini, S., Lee, J., Ebner, P. \& Zuelly, S.M.S., 2018. Dry-aging improves meat quality attributes of grass-fed beef loins. Meat Science 145, 285-291. https://doi.org/10.1016/J.MEATSCI.2018.07.004

Billett, M.A., Bruce, J.S., White, D.A., Bennett, A.J. \& Salter, A.M., 2000. Interactive effects of dietary cholesterol and different saturated fatty acids on lipoprotein metabolism in the hamster. British Journal of Nutrition 84, 439-447. https://doi.org/10.1017/S0007114500001744

Borghi, T.H., Garcia Da, A., Sobrinho, S., Maria, N., Lopes Zeola, B., Alves De Almeida, F., Gabriel, L., Cirne, A., Rebeca, A. \& Lima, C., 2016. Dietary glycerin does not affect meat quality of lle de France lambs. Bras. Zootec 45, 554-562. https://doi.org/10.1590/S1806-92902016000900008

Brouwer, I.A., Wanders, A.J. \& Katan, M.B., 2013. Trans fatty acids and cardiovascular health: research completed? European Journal of Clinical Nutrition 67, 541-547. https://doi.org/10.1038/ejcn.2013.43

Byelashov, O.A., Sinclair, A.J. \& Kaur, G., 2015. Dietary sources, current intakes, and nutritional role of omega-3 docosapentaenoic acid. Lipid Technology 27, 79-82. https://doi.org/10.1002/lite.201500013

Calder, P.C., 2015. Functional Roles of Fatty Acids and Their Effects on Human Health. Journal of Parenteral and 
Enteral Nutrition 39, 18S-32S. https://doi.org/10.1177/0148607115595980

Carvalho, G.A., Alburquerque, C.C., Sousa, A.M., Leite, E.R., Landim, A.V. \& Gomes, T.C.L., 2016. Caracterização do mercado da carne ovina em Sobral, estado do Ceará. Informações Economicas, SP 46.

Chikwanha, O.C., Vahmani, P., Muchenje, V., Dugan, M.E.R. \& Mapiye, C., 2018. Nutritional enhancement of sheep meat fatty acid profile for human health and wellbeing. Food Research International 104, 25-38. https://doi.org/10.1016/j.foodres.2017.05.005

CONAB, 2017. Indicadores da Agropecuária. Brasilia. https://doi.org/ISSN: 2317-7535

Costa, J.A. \& Gonzalez, C.L.M., 2014. Sheep farming for mutton production under integrated systems, in: Davi José Bungenstab and Roberto Giolo de Almeida (Ed.), Integrated Crop-Livestock-Forestry System. Embrapa, Brasilia, DF, p. 304.

de Abreu, K.S.F., Véras, A.S.C., de Andrade Ferreira, M., Madruga, M.S., Maciel, M.I.S., Félix, S.C.R., de Melo Vasco, A.C.C. \& Urbano, S.A., 2019. Quality of meat from sheep fed diets containing spineless cactus (Nopalea cochenillifera Salm Dyck). Meat Science 148, 229-235. https://doi.org/10.1016/J.MEATSCI.2018.04.036

Díaz, M.T., Álvarez, I., De La Fuente, J., Sañudo, C., Campo, M.M., Oliver, M.A., Font I Furnols, M., Montossi, F., San Julián, R., Nute, G.R. \& Cañeque, V., 2005. Fatty acid composition of meat from typical lamb production systems of Spain, United Kingdom, Germany and Uruguay. Meat Science 71, $256-263$. https://doi.org/10.1016/j.meatsci.2005.03.020

Djoussé, L. \& Gaziano, J.M., 2008. Egg consumption in relation to cardiovascular disease and mortality: the Physicians' Health Study. The American Journal of Clinical Nutrition 87, 964-969. https://doi.org/10.1093/ajcn/87.4.964

Faludi, A., Izar, M., Saraiva, J., Chacra, A., Bianco, H. \& Afiune Neto, A., 2017. Diretrizes Dislipdemia e arteroesclerose. Arquivos Brasileiros de Cardiologia 109. https://doi.org/10.1016/S0140-6736(11)60739-3.09-2015-VYT-13-BR-J

FAO, 2011. World Livestock 2011 Livestock in food security. Rome.

Feitosa Braga, L.F., Ferreira Olivieri, B., Aboujaoude, C., Simone, A., Pereira, C., Vinicius, M., De Lemos, A., Lucas, H., Chiaia, J., Piatto Berton, M., Peripolli, E., Adrielle, \&, Ferrinho, M., Lenise, \&, Mueller, F., Mônica, \&, Mazalli, R., Galvão De Albuquerque, L., Nunes De Oliveira, H., Tonhati, H., Espigolan, R., Lara Tonussi, R., Medeiros De Oliveira Silva, R., Gustavo, D., Gordo, M., Fabrícia, A., Magalhães, B., Aguilar, I., Fernando, B., \& Szydlowski, M., 2017. Genetic correlation estimates between beef fatty acid profile with meat and carcass traits in Nellore cattle finished in feedlot. Journal of Applied Genetics 58, 123-132. https://doi.org/10.1007/s13353-016-0360-7

Folch, J., Lees, M. \& Sloane Stanley, G.H., 1957. A simple method for the isolation and purification of total lipides from animal tissues. The Journal of biological chemistry 226, 497-509.

Fraser, M.D., Speijers, M.H.M., Theobald, V.J., Fychan, R. \& Jones, R., 2004. Production performance and meat quality of grazing lambs finished on red clover, lucerne or perennial ryegrass swards. Grass and Forage Science 59, 345-356. https://doi.org/10.1111/j.1365-2494.2004.00436.x

Granato, D., Araújo Calado, V.M. \& Jarvis, B., 2014. Observations on the use of statistical methods in Food Science and Technology. Food Research International 55, 137-149. https://doi.org/10.1016/J.FOODRES.2013.10.024

Hajji, H., Joy, M., Ripoll, G., Smeti, S., Mekki, I., Gahete, F.M., Mahouachi, M. \& Atti, N., 2016. Meat physicochemical properties, fatty acid profile, lipid oxidation and sensory characteristics from three North African lamb breeds, as influenced by concentrate or pasture finishing diets. Journal of Food Composition and Analysis 48, 102-110. https://doi.org/10.1016/j.jfca.2016.02.011

Hamley, S., 2017. The effect of replacing saturated fat with mostly $n-6$ polyunsaturated fat on coronary heart disease: a meta-analysis of randomised controlled trials. Nutrition Journal 16, 30. https://doi.org/10.1186/s12937-017-0254-5

Hartman, L. \& Lago, R.C., 1973. Rapid preparation of fatty acid methyl esters from lipids. Laboratory practice $22,475-6$ passim.

Iso, H., Sato, S., Umemura, U., Kudo, M., Koike, K., Kitamura, A., Imano, H., Okamura, T., Naito, Y. \& Shimamoto, T., 2002. Linoleic Acid, Other Fatty Acids, and the Risk of Stroke. stroke 33, 2086-2093. https://doi.org/10.1161/01.STR.0000023890.25066.50

Landim, A.V., Castanheira, M., Clorinda, M. \& Fioravanti, S., 2011. Physical , chemical and sensorial parameters for lambs of different groups, slaughtered at different weights. Tropical Animal Health and Production 43, 1089-1096. https://doi.org/10.1007/s11250-011-9806-4

Lôbo, A.M.B.O., Bomfim, M.A.D., Facó, O., Fernandes Júnior, A.G., Freire Ponciano, M. \& Lôbo, N.B.R., 2013. Intramuscular fat and fatty acid profile of muscle of lambs finished in irrigated pasture. Journal of Applied Animal Research 42, 110-117. https://doi.org/10.1080/09712119.2013.822810

Lourenço, M., Van Ranst, G., De Smet, S., Raes, K. \& Fievez, V., 2007. Effect of grazing pastures with different botanical composition by lambs on rumen fatty acid metabolism and fatty acid pattern of longissimus muscle and subcutaneous fat. Animal 1, 537-545. https://doi.org/10.1017/S1751731107703531

MAPA, 2017. Decreto 9.013 sobre Regulamento da inspeção industrial e sanitária de produtos de origem animal. Brasilia.

McNeill, S. \& Van Elswyk, M.E., 2012. Red meat in global nutrition. Meat Science 92, 166-173. https://doi.org/10.1016/J.MEATSCI.2012.03.014

Mizubuti, I.Y.., Pinto, A.P.., Pereira, E.S.., Ramos, B.M.O., 2009. Métodos laboratoriais de avaliação de alimentos para animais. Londrina, PR.

Montalvo-Puente, A.P., Torres-Gallo, R., Acevedo-Correa, D., Montero-Castillo, P.M. \& Tirado, D.F., 2018. Nutritional Comparison of Beef, Pork and Chicken Meat from Maracaibo City (Venezuela). Advance Journal of Food Science and Technology 15, 218-224. https://doi.org/10.19026/ajfst.15.5898

Montossi, F., Font-i-Furnols, M., del Campo, M., San Julián, R., Brito, G. \& Sañudo, C., 2013. Sustainable sheep production and consumer preference trends: Compatibilities, contradictions, and unresolved dilemmas. Meat 
Science 95, 772-789. https://doi.org/10.1016/j.meatsci.2013.04.048

Muchenje, V., Mukumbo, F.E., Descalzo, A.M. \& Schönfeldt, H.C., 2018. Introduction to the special issue on Balanced diets in food systems: emerging trends and challenges for human health and wellbeing. Food Research International 104, 1-3. https://doi.org/10.1016/j.foodres.2018.01.033

Nettleton, J.A., Lovegrove, J.A., Mensink, R.P. \& Schwab, U., 2016. Dietary Fatty Acids: Is it Time to Change the Recommendations? annals of nutrition and metabolism 68, 249-257. https://doi.org/10.1159/000446865

NRC, 2007. Nutrient Requirements of Small Ruminants. Sheep, Goats, Cervids, and New World Camelids. Washington DC.

O'Connell, T.D., Block, R.C., Huang, S.P. \& Shearer, G.C., 2017. w3-Polyunsaturated fatty acids for heart failure: Effects of dose on efficacy and novel signaling through free fatty acid receptor 4 . Journal of molecular and cellular cardiology 103, 74-92. https://doi.org/10.1016/j.yjmcc.2016.12.003

OECD, 2018. Meat consumption (indicator) [WWW Document]. https://doi.org/doi: 10.1787/fa290fd0-en

Pinto, K.M.S., De Melo, P.A.F.R., Do Nascimento, L.C., Cortez, M.I.G.M., Aires, A.A. de C., Mondego, J.M., Lima, R.P., Da Silva, E.C., Mesquita, M.L.R. \& De Lemos, R.N.S., 2018. Biological Potential of Extracts of Caatinga Plants in the Control of Alternaria alternata f. sp. citri in Citrus. Journal of Agricultural Science 10, 116. https://doi.org/10.5539/jas.v10n12p116

Rovadoscki, G.A., Pertile, S.F.N., Alvarenga, A.B., Cesar, A.S.M., Pértille, F., Petrini, J., Franzo, V., Soares, W.V.B., Morota, G., Spangler, M.L., Pinto, L.F.B., Carvalho, G.G.P., Lanna, D.P.D., Coutinho, L.L. \& Mourão, G.B., 2018. Estimates of genomic heritability and genome-wide association study for fatty acids profile in Santa Inês sheep. BMC genomics 19, 375. https://doi.org/10.1186/s12864-018-4777-8

Sacks, F.M., Lichtenstein, A.H., Wu, J.H.Y., Appel, L.J., Creager, M.A., Kris-Etherton, P.M., Miller, M., Rimm, E.B., Rudel, L.L., Robinson, J.G., Stone, N.J. \& Van Horn, L. V., 2017. Dietary fats and cardiovascular disease: A presidential advisory from the American Heart Association. Circulation 136, e1-e23. https://doi.org/10.1161/CIR.0000000000000510

Sales-Campos, H., Souza, P.R. de, Peghini, B.C., da Silva, J.S. \& Cardoso, C.R., 2013. An overview of the modulatory effects of oleic acid in health and disease. Mini reviews in medicinal chemistry 13, 201-10.

Santos-Silva, J., Bessa, R.J.B., Santos-Silva, F., 2002. Effect of genotype, feeding system and slaughter weight on the quality of light lambs. II. Fatty acid composition of meat. Livestock Production Science 77, 187-194. https://doi.org/10.1016/S0301-6226(02)00059-3

Santos, R.D., Gagliardi, A.C.M., Xavier, H.T., Magnoni, C.D., Cassani, R., Lottenberg, A.M. \& Sociedade Brasileira de Cardiologia-SBC, 2013. I Diretriz sobre o consumo de Gorduras e Saúde Cardiovascular. Aqrquivo Brasileiro de Cardiologia 100, 1-40. https://doi.org/10.5935/abc.2014S004

Siri-Tarino, P.W., Chiu, S., Bergeron, N., Krauss, R.M., Org;, P. \& Org, R., 2015. Saturated Fats Versus Polyunsaturated Fats Versus Carbohydrates for Cardiovascular Disease Prevention and Treatment. Annu Rev Nutr 35, 517-543. https://doi.org/10.1146/annurev-nutr-071714-034449

Siurana, A. \& Calsamiglia, S., 2016. A metaanalysis of feeding strategies to increase the content of conjugated linoleic acid (CLA) in dairy cattle milk and the impact on daily human consumption. Animal Feed Science and Technology 217, 13-26. https://doi.org/10.1016/J.ANIFEEDSCI.2016.04.013

Souza, R.J. de, Mente, A., Maroleanu, A., Cozma, A.I., Ha, V., Kishibe, T., Uleryk, E., Budylowski, P., Schünemann, H., Beyene, J. \& Anand, S.S., 2015. Intake of saturated and trans unsaturated fatty acids and risk of all cause mortality, cardiovascular disease, and type 2 diabetes: systematic review and meta-analysis of observational studies. BMJ (Clinical research ed.) 351, h3978. https://doi.org/10.1136/bmj.h3978

Stewart, B.W. \& Wild, C.P. (ed.), 2014. World Cancer Report 2014. International Agency for Research on Cancer, World Health Organization. Geneva, Switzerland.

Van Horn, L., Ann, J., Carson, S., Chair, V., Appel, L.J., Burke, L.E., Economos, C., Karmally, W., Lancaster, K., Lichtenstein, A.H., Johnson, R.K., Thomas, R.J., Vos, M., Wylie-Rosett, J. \& Kris-Etherton, P., 2016. recommended Dietary Pattern to Achieve Adherence to the American heart Association/American College of Cardiology (AhA/ACC) Guidelines A Scientific Statement from the American heart Association. Circulation 134, 505-529. https://doi.org/10.1161/CIR.0000000000000462

Wei, J., Hou, R., Xi, Y., Kowalski, A., Wang, T., Yu, Z., Hu, Y., Chandrasekar, E.K., Sun, H. \& Ali, M.K., 2018. The association and dose-response relationship between dietary intake of a-linolenic acid and risk of CHD: a systematic review and meta-analysis of cohort studies. British Journal of Nutrition 119, 83-89. https://doi.org/10.1017/S0007114517003294 